\title{
DIVERSITAS COCCINELLIDAE PREDATOR PADA EKOSISTEM PERTANAMAN CABAI DI TIGA KECAMATAN KABUPATEN KUANTAN SINGINGI
}

\author{
${ }^{1}$ Meli Aprilah, ${ }^{2}$ Rover, dan ${ }^{3} \mathrm{M}$ Siska Efendi \\ Program studi Agroteknologi \\ Fakultas Pertanian \\ Universitas Islam Kuantan Singingi 2015 \\ Email : meliaprila.uniks@ gmail.com \\ Program studi Agroteknologi \\ Fakultas Pertanian \\ Universitas Islam Kuantan Singingi 2015 \\ Email : Roverblazer@yahoo.com \\ Program studi Agroteknologi \\ Fakultas Pertanian \\ Universitas Islam Kuantan Singingi 2015
}

Email : siskaefendichiko@gmail.com

\begin{abstract}
ABSTRAK
Diversitas Coccinellidae Predator Pada Ekosistem Pertanaman Cabai di Tiga Kecamatan Kabupaten Kuantan Singingi. Penelitian tenatang keanekaragaan dan kelimpahan Coccinellidae Predator di pertanaman cabai telah dilakukan di Kecamatan Benai, Kecaatan Kuantan Tengah dan Kecamatan Gunung Toar selama tiga bulan Desember-Februari. Penelitian bertujuan untuk mempelajari keanekaragaman, kemerataan dan kekayaan Coccinellidae Predator. Pengambilan sampel spesies Coccinellidae Predator dilakukan dengan menggunakan jaring ayun dan koleksi secara langsung pada tajuk tanaman. Keanekaragaman Coccinellidae Predator dihitung menggunakan ShannonWienner. Total jumlah Coccinellidae predator yang telah dikumpulkan dalam penelitian ini adalah 146 individu yang terdiri dari 11 spesies, spesies predator yang ditemukan di pertanaman cabai adalah Chilocorus melanophthalmus, Coccinella repanda, Coelophora 9 maculata, Coelophora inaequalis, Illeis cincta, Menochilus sexmaculatus, Ropaloneda decussata, Verania discolor, Verania lineata, Spesies 1 yang mempunyai potensi yang baik untuk mengendalikan kutu daun di pertanaman cabai.
\end{abstract}

KATA KUNCI: Coccinellidae Predator, keanekaragaman, kemerataan, dan kekayaan.

\section{Pendahuluan}

Kutu daun (Aphididae) komoditas penting dari famili tergolong hama utama (mayor pest) Solanaceae yakni tanaman cabai pada beberapa tanaman holtikultura, (Capsicum annuum L). Aphididae pangan dan perkebunan. Hama ini menyerang tanaman cabai dengan bersifat polifag menginvansi lebih dari cara menghisap cairan daun, pucuk, 100 jenis tanaman inang, dari 77 tangkai bunga atau pun bagian famili, diantaranya famili Fabaceae, tanaman lain, sehingga daun menjadi Asteraceae, Malvaceae, Euphorbiaceae, dan Solanaceae belang-belang kekuningan (klorosis) daun keriting, pucuk berkerut dan (Lanjar \& Sahito, 2007). Salah satu melingkar dan akhirnya rontok 
sehingga produksi cabai menurun (Setiadi, 1993).

Upaya pengendalian Aphididae masih bertumpu pada penggunaan insektisida, karena cara-cara yang lain seperti penggunaan varietas tahan, kultur teknis, fisik dan mekanis belum mampu memberikan hasil yang optimal. Pengendalian Aphididae menggunakan insektisida sudah biasa di lakukan, jika populasi sudah melewati ambang pengendalian. Penggunaan insektisida tanpa didasari pengetahuan bioekologi hama dan teknik aplikasi yang benar mengakibatkan tidak tercapainya tujuan pengendalian, bahkan dapat menyebabkan terjadinya kasus resistensi dan resurjensi (Marwoto, 1992).

Untuk mengurangi dampak negatif penggunaan insektisida tersebut, maka pengendalian hama secara konvensional (menggunakan insektisida) mulai ditinggalkan dan beralih pada pengendalian berdasarkan konsep Pengelolaan Hama Terpadu (PHT) (Mangoendiharjo \& Mahrub, 1983).

Agensia pengendali hayati yang banyak dimanfaatkan adalah serangga predator. Salah satu predator efektif untuk mengendalikan Aphididae adalah Coccinellidae predator. Coccinellidae predator tergolong kelompok serangga yang banyak jenisnya. Di Indonesia

\section{Bahan dan Metode}

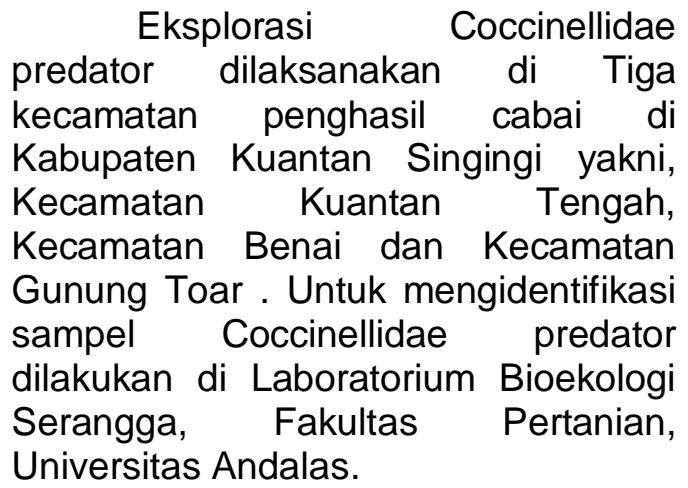

diperkirakan lebih dari 300 jenis yang tersebar luas dan dijumpai hampir sepanjang tahun. Sebagian besar jenis dari Coccinellidae, baik larva dan dewasanya sebagai pemangsa (predator) dari serangga-serangga kecil yang berbadan lunak misalnya Aphididae, kutu sisik, dan telur serangga (Amir, 2002).

Keanekaragaman Coccinellidae predator yang tinggi merupakan sumber daya besar yang dapat dimanfaatkan sebagai agensia pengendali hayati. Sesungguhnya banyak jenis Coccinellidae predator di Indonesia yang memiliki potensi besar dalam pengendalian populasi beberapa jenis hama tanaman (Mangundiharjo, 1990). Namun pengetahuan tentang Coccinellidae predator tidak cukup, baik pengena' jenis maupun perilakunya. Informá. jenis-jenis dari berbagai daerah di Indonesia tidak lengkap (Amir, 2002), termasuk di lokasi penelitian, padahal menurut Sosromarsono dan Untung (2000) penelitian keanekaragaman baik dari musuh alami dan mangsa atau inangnya adalah dasar bagi pengembangan teknik pengendalian hayati yang akan dilakukan, khususnya konservasi dan augmentasi. Berdasarkan uraian di atas maka penulis melakukan penelitian dengan judul "Diversitas Coccinellidae Predator Pada Beberapa Ekosistem Pertanaman Cabai di Tiga Kecamatan Kabupaten Kuantan Singingi".

Alat yang digunakan meliputi: (1) alat untuk mengoleksi serangga di lapangan (botol film, jaring ayun dan kotak plastik) (2) alat identifikasi Coccinellidae predator (mikroskop binokuler, pinset, cawan petri dan kamera) (3) alat pengamatan (buku induk pengamatan, pensil, dan spidol). Bahan yang digunakan adalah alkohol $70 \%$ untuk mengawetkan Coccinellidae predator dan mikrotube. 
Pengamatan

keanekaragaman

predator dilakukan untuk

menggambarkan jumlah spesies dan kelimpahan serangga tersebut di ekosistem pertanaman cabai. Penelitian ini berbentuk survei yaitu melakukan pengamatan secara langsung (visual) dan koleksi dengan menggunakan alat penangkap seperti jaring ayun (sweep net) (Radiyanto et al. 2010). Metode pengambilan sampel yang digunakan adalah Purposive Random Sampling. Pada masingmasing lokasi penelitian, dipilih dua petak pertanaman cabai (Lampiran 2). Pada tiap petak pertanaman ditentukan petak sampel yang berukuran $1 \times 1 \mathrm{~m}^{2}$ secara sistematis pada garis diagonal, sehingga didapatkan 5 petak sampel (Meidiwarman, 2010). Pada satu petak sampel $\left(1 \times 1 \mathrm{~m}^{2}\right)$ hanya ditentukan empat tanaman cabai sebagai objek pengamatan. Pengambilan sampel Coccinellidae predator di lapangan dilakukan sebanyak tiga kali dan interval pengambilan sampel seminggu sekali. Sebagai data penunjang juga diamati umur tanaman cabai, jenis pestisida yang digunakan petani dan kondisi pertanaman lain di sekitar petak pengamatan.

Pengambilan

sampel

Coccinellidae predator dilakukan dengan dua metode. Pertama koleksi secara langsung (hand picking) yaitu menangkap dengan tangan setiap Coccinellidae predator yang ditemukan pada petak sampel (Zahoor et al. 2003). Metode yang kedua menggunakan jaring ayun (Sweep Sampling Method) yaitu mengoleksi Coccinellidae predator yang berada pada tajuk tanaman (Gadagkar et al .1990).

Pengambilan sampel Coccinellidae predator dilakukan di setiap petak pertanaman dengan mengayunkan jaring ke kiri dan ke kanan secara bolak-balik sebanyak 20 kali sambil berjalan (Hendrival et al . 2011). Coccinellidae predator yang tertangkap disimpan dalam botol koleksi yang telah diisi dengan larutan alkohol $70 \%$ untuk selanjutnya diidentifikasi di Laboratorium Bioekologi Serangga Fakultas Pertanian Universitas Andalas.

Identifikasi dilakukan dengan mengamati spesimen serangga. Identifikasi spesimen menggunakan ciri-ciri morfologi sayap, antena dan toraks. Spesimen Coccinellidae predator yang diperoleh di lapangan diidentifikasi sampai tingkat spesies mencocokkan spesimen dengan gambar dan keterangan dari buku "Kumbang Lembing di Indonesia" (Amir, 2002) dan www.coccinellidae.net. dan www.discoverlife.org.

Keanekaragaman spesies Coccinellidae predator dapat diukur dengan menggunakan indeks keanekaragaman Shannon-Wienner (Krebs, 1999). Persamaan indeks keanekaragaman Shannon-Wienner adalah sebagai berikut :

$$
\begin{aligned}
& \mathrm{H}=-\sum_{\mathrm{Pi}} \mathrm{Pi}(\log \text { e. } \mathrm{Pi}) \\
& \mathrm{Pi}=\mathrm{n} / \mathrm{N}
\end{aligned}
$$

Keterangan :

$\mathrm{H}=$ Indeks Keanekaragaman Shannon-Wienner

$\mathrm{Pi}=$ Proporsi individu spesies ke-i pada komunitas

$\mathrm{n} \quad=$ Kelimpahan individu spesies kei

$\mathrm{N}$ = Jumlah total individu semua spesies

Kemerataan spesies adalah proporsi masing-masing spesies dalam suatu komunitas. Kemerataan spesies dapat dihitung menggunakan indeks kemerataan Simpson's (Krebs, 1999). Persamaan indeks kemerataan Simpson's adalah sebagai berikut:

$$
\begin{aligned}
& \mathrm{D}=1-\sum \mathrm{Pi}^{2} \\
& \text { Keterangan : }
\end{aligned}
$$

$\mathrm{D}=$ Indeks kemerataan Simpson`s

$\mathrm{Pi}=$ Proporsi individu spesies ke-i 
Kekayaan spesies diperoleh berdasarkan jumlah total spesies yang dikoleksi pada masing-masing lokasi penelitian. Data komposisi spesies dan jumlah individu Coccinellidae predator digunakan untuk menganalisis keanekaragaman dan kemerataan. Ukuran keanekaragaman yang dipergunakan ialah nilai indeks

\section{Hasil}

\section{Deskripsi Lokasi Penelitian}

Ekosistem di tiga lokasi pengambilan sampel yakni Kec. Benai, Kec. Kuantan Tengah dan Kec. Gunung Toar cukup beragam. Keragaman tersebut dapat dilihat dari kondisi tanaman sekitar, pola budidaya Tabel 1. Deskripsi lokasi penelitian *

\begin{tabular}{|c|c|c|c|c|}
\hline Lokasi penelitian & $\begin{array}{c}\text { Tanaman } \\
\text { sekitar }\end{array}$ & $\begin{array}{c}\text { Pola budidaya } \\
\text { cabai }\end{array}$ & Pestisida & $\begin{array}{l}\text { Aplikasi } \\
\text { Pestisida }\end{array}$ \\
\hline $\begin{array}{l}\text { Kec. Benai } \\
\text { a.Desa Benai } \\
\text { Kecil }\end{array}$ & $\begin{array}{l}\text { Tanaman } \\
\text { jagung }\end{array}$ & $\begin{array}{lr}\text { Varietas lado } \\
\text { F1, r umur } \\
\text { tanaman } 90 \\
\text { hst, jarak } \\
\text { tanam } 60 \times 70 \\
\text { cm, } \\
\text { menggunakan } \\
\text { mulsa }\end{array}$ & $\begin{array}{l}\text { Pestisida } \\
\text { yang di } \\
\text { gunakan } \\
\text { adalah } \\
\text { starmex, } \\
\text { decis, } \\
\text { curacron, } \\
\text { regent, } \\
\text { antracol, } \\
\text { perpektan } \\
\text { dan seprint. }\end{array}$ & $\begin{array}{l}\text { Aplikasi } \\
\text { pestisida } \\
\text { di lakukan } \\
\text { tiga kali } \\
\text { dalam } \\
\text { seminggu }\end{array}$ \\
\hline $\begin{array}{l}\text { b. Desa } \\
\text { Simandolak }\end{array}$ & $\begin{array}{l}\text { Tidak } \\
\text { terdapat } \\
\text { tanaman lain } \\
\text { di sekitar } \\
\text { pertanaman } \\
\text { cabai }\end{array}$ & $\begin{array}{lr}\text { Varietas lado } \\
\text { F1, } & \text { umur } \\
\text { tanaman } 100 \\
\text { hst, jarak } \\
\text { tanam } \\
\text { cm } \\
\text { menggunakan } \\
\text { mulsa }\end{array}$ & $\begin{array}{l}\text { Pestisida } \\
\text { yang } \\
\text { digunakan } \\
\text { adalah } \\
\text { starmex, } \\
\text { decis, } \\
\text { curacron, } \\
\text { regent, } \\
\text { antracol, } \\
\text { perpektan } \\
\text { dan seprint }\end{array}$ & $\begin{array}{l}\text { Aplikasi } \\
\text { pestisida } \\
\text { di lakukan } \\
\text { dua kali } \\
\text { dalam } \\
\text { seminggu }\end{array}$ \\
\hline
\end{tabular}

Kec. Kuantan

Tengah

$\begin{array}{cllll}\text { a. Desa } & \text { Tanaman } & \text { Varietas lado Pestisida } & \text { Aplikasi } \\ \text { Kari } & \text { pepaya, } & \text { F1, umur yang } & \text { pestisida } \\ & \text { singkong, } & \text { tanaman } 100 \text { digunakan } & \text { di lakukan } \\ & \text { buah naga, } & \text { hst, jarak adalah, } & \text { dua } \\ & & \text { tanam 50x50 decis, } & \text { minggu } \\ & & \text { cm } & \text { curacron, } & \text { sekali }\end{array}$

keanekaragaman spesies ShannonWienner dan indeks kemerataan Simpson menggunakan buku Magurran (1988). Analisis data menggunakan program Primer versi 5 For Window dan BioDiversity Professional versi 2. Semua hasil analisis tersebut ditampilkan dalam bentuk tabel.

cabai, penggunaan pestisida dan aplikasi, serta metode pengendalian hama dan penyakit. Secara umum deskripsi lokasi penelitian dapat dilihat pada Tabel 1. dan seprint 


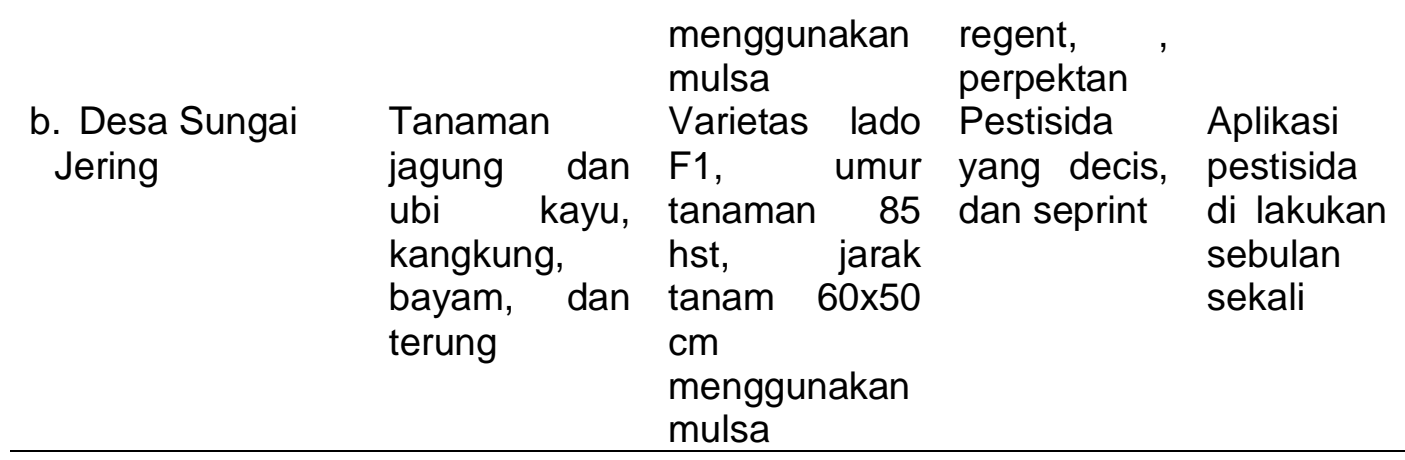

Kec. Gunung

Toar

\begin{tabular}{|c|c|c|c|c|}
\hline $\begin{array}{l}\text { a. Desa } \\
\quad \text { Petapahan }\end{array}$ & $\begin{array}{l}\text { Tanaman } \\
\text { pepaya }\end{array}$ & $\begin{array}{lr}\text { Varietas } & \text { lado } \\
\mathrm{F} 1, & \text { umur } \\
\text { tanaman } & 70 \\
\text { hst, } & \text { jarak } \\
\text { tanam } & 60 \times 70 \\
\mathrm{~cm} & \\
\text { menggunakan. }\end{array}$ & $\begin{array}{l}\text { Pestisida } \\
\text { yang } \\
\text { digunakan } \\
\text { adalah } \\
\text { starmex, } \\
\text { decis, } \\
\text { curacron, } \\
\text { regent, } \\
\text { anrtacol, }\end{array}$ & $\begin{array}{l}\text { Aplikasi } \\
\text { pestisida } \\
\text { di lakukan } \\
\text { seminggu } \\
\text { sekali }\end{array}$ \\
\hline $\begin{array}{c}\text { b. Desa Pulau } \\
\text { Rumput }\end{array}$ & $\begin{array}{l}\text { Tanaman } \\
\text { jagung }\end{array}$ & $\begin{array}{lr}\text { Varietas lado } \\
\text { F1, } \\
\text { tanaman } \\
\text { hst, } 85 \\
\text { tanam } \\
\text { cm } \\
\text { mengarak } \\
\text { mulsa }\end{array}$ & $\begin{array}{l}\text { Pestisida } \\
\text { yang } \\
\text { digunakan } \\
\text { adalah } \\
\text { starmex, } \\
\text { decis, } \\
\text { curacron, } \\
\text { regent, } \\
\text { antracol, } \\
\text { perpektan } \\
\text { dan seprint }\end{array}$ & $\begin{array}{l}\text { Aplikasi } \\
\text { pestisida } \\
\text { di lakukan } \\
\text { seminggu } \\
\text { sekali }\end{array}$ \\
\hline
\end{tabular}

*Sumber : wawancara secara pribadi dilapangan dengan petani pemilik lahan

2. Deskripsi Spesies

\section{Coccinellidae Perdator Yang Di}

Koleksi Di Lapangan

Ditemukan sebanyak 146 individu Coccinellidae predator pada ekosistem pertanaman cabai di Kec. Benai, Kec. Kuantan Tengah dan Kec. Gunung Toar. Coccinellidae predator yang

\section{Kelimpahan Coccinellidae} Predator Berdasarkan

\section{Kecamatan}

Total jumlah Coccinellidae predator yang telah dikumpulkan dalam penelitian ini adalah 146 individu yang terdiri dari 11 spesies. Jumlah Coccinellidae predator yang dikumpulkan di Kec. Benai yaitu 43 dikoleksi selama penelitian berjumlah 11 spesies. Dari 11 spesies yang dikoleksi hanya 9 spesies yang teridentifikasi, sedangkan 2 spesies lagi belum teridentifikasi.

individu yang terdiri dari 6 spesies, di Kec. Gunung Toar 36 individu yang terdiri dari 6 spesies dan di Kec. Kuantan Tengah 67 individu yang terdiri dari 9 spesies. 
Jika dilihat kelimpahan Coccinellidae predator pada tiga kecamatan pengamatan yang tertinggi terdapat pada kec. Kuantan Tengah predator yang di sebabkan oleh pengaplikasi pestisida yang berbeda di masing-masing petani, di Kec. Kuantan Tengah melakukan penyemprotan pestisida sebulan sekali sedangkan di Kec. Gunung Toar melakuakan

Tabel 3. Jumlah individu dan populasi Coccinellidae predator pada beberapa
(67 ekor) sedangkan yang terendah terdapat pada Kec. Gunung Toar (36 ekor). Ketidak samaan kelimpahan Coccinellidae

penyemprotan seminggu sekali. Dengan demikian pestisida juga termasuk salah satu faktor yang menyebabkan kelimpahan Coccinellidae predator tidak merata.

\section{kecamatan pengambilan sampel}

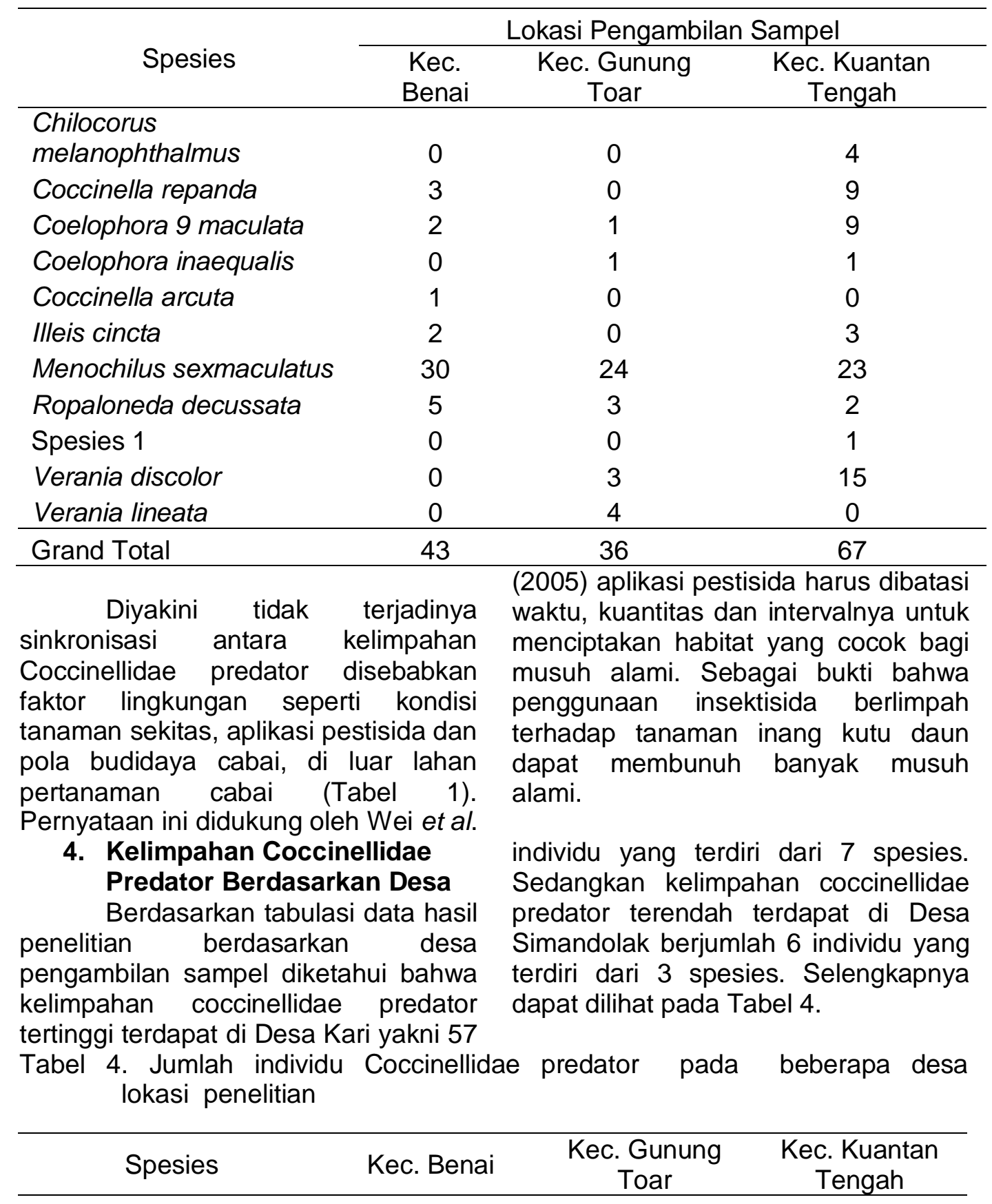




\begin{tabular}{|c|c|c|c|c|c|c|}
\hline & ${ }^{*} \mathrm{BK}$ & S & $P$ & PR & $\mathrm{K}$ & SJ \\
\hline Chilocorus & & & & & & \\
\hline melanophthalmus & 0 & 0 & 0 & 0 & 4 & 0 \\
\hline Coccinella repanda & 1 & 2 & 0 & 0 & 9 & 0 \\
\hline Coelophora 9 maculata & 2 & 0 & 1 & 0 & 8 & 1 \\
\hline Coelophora inaequalis & 0 & 0 & 0 & 1 & 0 & 1 \\
\hline Coccinella arcuta & 1 & 0 & 0 & 0 & 0 & 0 \\
\hline $\begin{array}{l}\text { Illeis cincta } \\
\text { Menochilus }\end{array}$ & 2 & 0 & 0 & 0 & 1 & 2 \\
\hline sexmaculatus & 27 & 3 & 17 & 7 & 21 & 2 \\
\hline Ropaloneda decussata & 4 & 1 & 0 & 3 & 0 & 2 \\
\hline Spesies 1 & 0 & 0 & 0 & 0 & 1 & 0 \\
\hline Verania discolor & 0 & 0 & 2 & 1 & 13 & 2 \\
\hline Verania lineata & 0 & 0 & 2 & 2 & 0 & 0 \\
\hline Grand Total & 37 & 6 & 22 & 14 & 57 & 10 \\
\hline
\end{tabular}

*Catatan : BK : Benai Kecil, S : Simandolak, P : Petapahan, PR Pulau Rumput, $\mathrm{K}$ : Kari, SJ : Sungai Jering

Kelimpahan
Predator berkaitan erat dengan
vegetasi tumbuhan sekitar lahan.
Dilaporkan oleh Outward et al. (2008)
penanaman vegetasi tumbuhan di
sekitar kapas dapat mengurangi
kepadatan populasi $A$. gossypii dan
dapat meningkatkan kelimpahan
arthropoda predator. Menurut
Kuznetsov dan Zakharov (2001) salah
satu faktor yang mempengaruhi
penyebaran kumbang Coccinellidae di

5. Indeks Keanekaragaman, Kekayaan dan Kemerataan Spesies Berdasarkan
Rusia adalah kekayaan flora. Menurut Brewer dan Elliot (2004) keanekaragaman tumbuhan yang berada di sekitar tanaman budidaya dapat mempengaruhi kehadiran predator. Artinya koloni predator di lahan pertanian berasal dari vegetasi sekitar lahan. Kelimpahan serangga predator secara umum dipengaruhi oleh keanekaragaman habitat, kualitas dan keterhubungan habitat dalam suatu lanskap.

keanekaragaman yakni 1,06 dan kemerataan spesies yakni 0,50.

Pada penelitian ini, nilai indeks keanekaragaman dan kemerataan Coccinellidae predator berdasarkan Kecamatan tertinggi didapatkan pada ekosistem pertanaman cabai di Kec. Kuantan Tengah yakni indeks keanekaragaman 1,78 dan kemerataan 0,80. Di Kec. Gunung Toar nilai indeks keanekaragaman dan kemerataan berturut-turut yakni 1,13 serta 0,54 . Nilai indeks yang terendah terdapat di Kec. Benai dengan indeks Tabel 5. Indeks keanekaragaman, kekayaan, kemerataan spesies dan jumlah individu Coccinellidae predator pada pertanaman cabai di pada tiga Kecamatan lokasi penelitian 


\begin{tabular}{lcccc}
\hline \multirow{2}{*}{ Lokasi } & \multicolumn{4}{c}{ Nilai Indeks } \\
\cline { 2 - 5 } & $\begin{array}{c}\text { Kekayaa } \\
\mathrm{n}\end{array}$ & $\begin{array}{c}\text { Kelimpaha } \\
\mathrm{n}\end{array}$ & $\begin{array}{c}\text { Keanekaragama } \\
\mathrm{n}\end{array}$ & Kemerataan \\
\hline Kec. Benai & 6 & 43 & 1,06 & 0,50 \\
Kec. Gunung Toar & 6 & 36 & 1,13 & 0,54 \\
$\begin{array}{l}\text { Kec. Kuantan } \\
\text { Tengah }\end{array}$ & 9 & 67 & 1,78 & 0,80 \\
\hline
\end{tabular}

Coccinellidae predator terbanyak ditemukan di Kec. Kuantan Tengah, sebanyak 9 spesies, di Kec. Gunung Toar sebanyak 6 spesies, dan di Kec. Benai sebanyak 6 spesies. Hal ini diikuti pula oleh kecenderungan lebih tingginya indeks keanekaragaman Coccinellidae predator pada tanaman cabai tersebut pada beberapa daerah penelitian.

Banyaknya

Coccinellidae predator yang ditemukan di sebabkan oleh tanaman sekitar, pola budidaya cabai, pestisida dan pengaplikasi pestisida yang berbeda di masingmasing petani. Kec. Kuantan tengah memiliki tanaman sekitar yang beragam banyak petani mengkobinasikan tanaman cabai dengan tanaman lainya seperti, tanaman pepaya, singkong, buah naga, jaggung, kangkung, bayam dan terung. Jika di lihat dari pola budidaya tanaman cabai menggunakan varietas F1 umur tanaman 85-100 Hst dengan

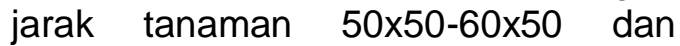
menggunakan mulsa. Pestisida dan pengaplikasian pestisida juga sangat berpengaruh pestisida yang digunakan adalah decis, curacron, regent dengan jarak interval penyemprotan dilakukan dua kali seminggu sampai satu bulan sekali.

\section{Indeks Keanekaragaman, Kekayaan dan Kemerataan Spesies Berdasarkan Desa}

Pada penelitian ini, nilai indeks keanekaragaman Coccinellidae predator berdasarkan desa tertinggi didapatkan pada ekosistem pertanaman cabai di Desa Sungai Jering yakni indeks keanekaragaman (nilai indeks 1,75); kemerataan spesies (nilai indeks 0,91); Desa Kari dengan indeks keanekaragaman (nilai indeks 1,60 ), kemerataan spesies (nilai indeks 0,78); Desa Pulau Rumput dengan indeks keanekaragaman (nilai indeks
1,33), kemerataan spesies (nilai indeks 0,73); Desa Simandolak dengan indeks keanekaragaman (nilai indeks 1,01 ), kemerataan spesies (nilai indeks 0,73 ); Desa benai Kecil dengan indeks keanekaragaman (nilai indeks 0,98), kemerataan spesies (nilai indeks 0,46 ); dan yang paling rendah terdapat di Desa Petapahan dengan indeks keanekaragaman (nilai indeks 0,78), dan kemerataan spesies (nilai indeks $0,40)$.

Tabel 6. Indeks keanekaragaman, kekayaan, dan kemerataan spesies Coccinellidae predator pada beberapa desa lokasi penelitian 


\begin{tabular}{|c|c|c|c|c|}
\hline & $\begin{array}{l}\text { Kekayaa } \\
\mathrm{n}\end{array}$ & Kelimpahan & $\begin{array}{l}\text { Keanekaragama } \\
\mathrm{n}\end{array}$ & $\begin{array}{l}\text { Kemerataa } \\
\mathrm{n}\end{array}$ \\
\hline Benai Kecil & 6 & 37 & 0,98 & 0,46 \\
\hline Simandolak & 3 & 6 & 1,01 & 0,73 \\
\hline Petapahan & 4 & 22 & 0,78 & 0,40 \\
\hline Pulau rumput & 5 & 14 & 1,33 & 0,73 \\
\hline Kari & 7 & 57 & 1,60 & 0,78 \\
\hline Sungai Jering & 6 & 10 & 1,75 & 0,91 \\
\hline
\end{tabular}

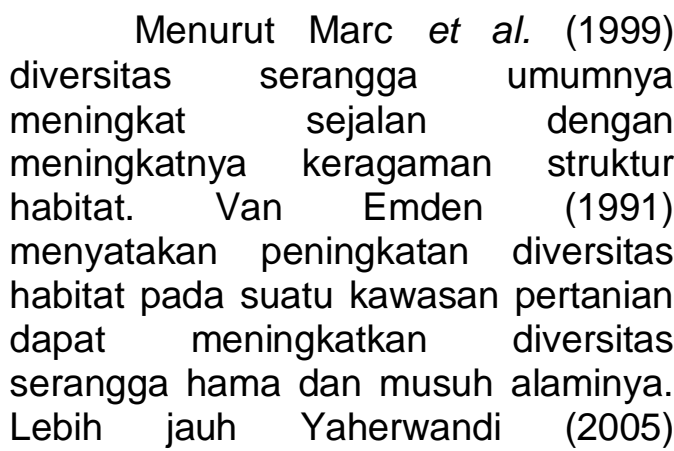
menyatakan, diversitas tumbuhan akan membentuk struktur komunitas yang lebih kompleks sehingga habitat suatu daerah mampu menyediakan berbagai sumber daya seperti inang alternatif, sumber makanan, habitat tanaman lain sebagai tempat berlindung dan ketersediaan makanan yang sesuai bagi kelangsungan hidup dan diversitas serangga tertentu.

\section{Kesimpulan dan Saran} Kesimpulan

Berdasarkan hasil penelitian
tentang diversitas Coccinellidae
predator pada pada beberapa
ekosistem pertanaman cabai di
Kabupaten Kuantan Singingi dapat
kesimpulan:

1. Total spesies Coccinellidae predator yang ditemukan yakni 11 spesies, 10 spesies diantaranya sudah diidentifikasi, sedangkan 1 spesies lain belum teridentifikasi.

2. Indeks keanekaragaman, kekayaan, dan kemerataan spesies Coccinellidae predator tertinggi di lokasi Kec. Kuantan Tengah dan yang terendah di Kec. Benai. Sedangkan berdasarkan desa, ditemukan indeks keanekaragaman tertinggi di Desa Sungai Jering.

3. Menochilus sexmaculatus spesises yang paling melimpah dan penyebaran merata disemua lokasi penelitian.

\section{Saran}

Diharapkan penelitian tentang Coccinellidae Predator pada pertanaman cabai dilanjutkan mengenai bioekologi masing-masing spesies yang sudah teridentifikasi.

\section{Daftar Pustaka}

Amir. 2002. Kumbang Lembing Pemangsa Coccinellidae di Indonesia. Bogor : Puslit BiologiLIPI.

Gadagkar R, Chandrashaekara K, Nair P. 1990. Insect species diversity in the tropics: sampling method and case study. Journal of Bombay Natural History Society. 87: 328-353

Hendrival, Hidaya P, Nurmansyah A. 2011. Keanekaragaman dan kelimpahan musuh alami Bemisia tabaci (gennadius) (hemiptera: aleyrodidae) pada pertanaman cabai merah di Kecamatan Pakem, Kabupaten Sleman, Daerah Istimewa Yogyakarta. J Entomol Indon 8(2):96-109. 
Lanjar AG, Sahito HA. 2007. Impact of weeding on whitefly population on okra crop Park. J Weed Sci 13(3-4):209-217.

Magurran AE. (1988). Ecological

Diversity and Its Measurement . USA:Princeton University Press.

Mangundiharjo S, Mahrub E, Warrow J. 1990. Endemic natural enemies of the leucena psyllids in Indonesia; In Proceeding of an Internasional Workshop held in Bogor: Institut Pertanian Bogor.

Mangoendihadjo S, Mahrub E. 1983. Pengendalian Hayati. Yogyakarta: Gajah Mada University Prees.

Marwoto, 1992. Masalah Pengendalian Hama Kedelai Tingkat Petani. Risalah Lokakarya Pengendalian Hama Terpadu Tanaman Kedelai. Balai Penelitian Pangan: Malang

Meidiwarma. 2010. Studi arthopoda predator pada ekosistem tanaman tembakau virginia di lombok tengah. $J$ Crop Agro 3(2):92-96.

Riyanto. 2010. Kelimpahan serangga predator kutu daun (Aphis gossypii) sebagai sumbangan materi kontekstual pada mata kuliah entomologi di program studi pendidikan biologi.[Laporan Penelitian].Universitas Sriwijaya , Inderalaya

Setiadi. 1993. Bertanam Cabe.

Jakarta: Penebar Swadaya.

Untung K. 1993. Pengendalian Hama Terpadu. Yogyakarta: Gadjah Mada University.

Krebs CJ. 1999. Ecological Metodology. Second Edition. New York: An Imprint of Addison Wesley Longman, Inc

Zahoor M, Anwar M. 2003. Biodiversity of predaceous Coccinellids and their role as bioindicators in an Agro-ecosystem. International Journal of Agriculture and Biology 5(4):555-559 